\title{
Leaving Light Footprints - the Importance of Promoting Responsible International Travel
}

\author{
Bryan Chang Wei Lim ${ }^{1,2}$, Gerard Thomas Flaherty ${ }^{1,2^{*}}$ \\ ${ }^{1}$ School of Medicine, National University of Ireland Galway, Galway, Ireland \\ ${ }^{2}$ School of Medicine, International Medical University, Kuala Lumpur, Malaysia
}

Corresponding Author: Gerard Flaherty, MD, Professor, School of Medicine, National University of Ireland Galway, Galway, Ireland. Tel: +353-91495469, Email: gerard.flaherty@nuigalway.ie

Received April 25, 2018; Accepted September 7, 2018; Online Published September 25, 2018

\begin{abstract}
Irresponsible travel has the potential to harm both the traveler and the host destination. The subject of responsible travel is a major focus of the International Society of Travel Medicine, whose Responsible Travel special interest group has been very active in providing leadership for travel medicine practitioners in relation to the protection of local travel destination communities. Healthcare professionals have a responsibility to safeguard the dual interests of travelers and their hosts. This can be achieved by drawing the traveler's attention to examples of irresponsible tourism during the pre-travel consultation. This perspective article aims to explore various aspects of irresponsible travel, including environmental damage travelers may cause; medical tourism and its impact on both the home and destination health service; voluntourism involving poorly prepared volunteers interacting with vulnerable communities in the host country; and sex tourism, including prostitution and child trafficking. Further research is needed to better understand the attitudes of travelers, travel health professionals, and the travel industry towards responsible tourism and to overcome barriers to its implementation.

Keywords: Responsible Travel, Ethical, Medical Tourism, Sex Tourism, Volunteering
\end{abstract}

Citation: Lim BCW, Flaherty GT. Leaving light footprints - the importance of promoting responsible international travel. Int J Travel Med Glob Health. 2018;6(3):88-91. doi:10.15171/ijtmgh.2018.18.

\section{Introduction}

International travel is a privilege, not a basic human right. All of life's privileges come with certain inherent responsibilities. Global travel has expanded exponentially, such that annual tourist arrivals have been predicted by the World Tourism Organization to reach 1.8 billion by $2030 .{ }^{1}$ The ease of modern air and cruise ship transportation has combined with the increased prosperity of developing countries to greatly facilitate international travel. Current international travel trends have highlighted the sharp increase in outward travel from emerging economies in regions such as Asia and Africa. ${ }^{2}$ Travel overseas should be symbiotic; the traveler should benefit from exposure to other cultures and natural environments, while the destination community may also benefit socially and economically. However, irresponsible travel has the potential to harm both the traveler and the host destination and lead to unforeseen consequences.

The subject of responsible travel is a major focus of the International Society of Travel Medicine (ISTM), whose Responsible Travel special interest group has been very active in providing leadership for travel medicine practitioners in relation to the protection of local travel destination communities from the undesirable impacts of tourism. ${ }^{3}$ Areas of particular expertise within the ISTM group include ethical tourism, voluntourism, and sex tourism. Healthcare professionals have an onus of responsibility to safeguard the dual interests of travelers and their hosts. This can be achieved by drawing the traveler's attention to examples of irresponsible tourism during the pre-travel consultation. It behooves the travel medicine professional community to maintain a heightened awareness of the importance of responsible travel through education of travelers and the travel industry. The issue of responsible tourism has been somewhat neglected to date in the travel medicine literature. ${ }^{4}$ This perspective article will explore various aspects of responsible travel with a particular focus on voluntourism, sex and romance tourism, and medical tourism.

\section{Environmental Effects of Travel}

Modern international travel is, by its very nature, damaging to the natural environment. Jet fuel carbon emissions contribute to anthropogenic climate change and increase the carbon

Copyright $(\subset 2018$ The Author(s). This is an open-access article distributed under the terms of the Creative Commons Attribution License (http:// creativecommons.org/licenses/by/4.0), which permits unrestricted use, distribution, and reproduction in any medium, provided the original work is properly cited. 
footprint of individual travelers. While a mechanism exists to offset travel-related carbon emissions, ${ }^{5}$ it is unknown how many travelers actually choose this responsible option owing to the individual cost involved. This environmental impact is greater with more frequent travel such as business travel. The development of non-fossil-based fuels by the aviation industry (for example, hydrogen and solar powered air-craft) will hopefully address this issue in the future.

The responsible traveler should be aware of the effect of his/ her personal consumption behavior on the local environment of the host country. One example is the overuse of disposable plastic water bottles by trekkers along the Everest Base Camp trail in Nepal. There should be cooperation between destinations and the travel industry to enable travelers to recycle materials when they travel as they would domestically. Travelers should be conscious of the importance of conserving fragile natural habitats and scarce local resources such as clean water. Recent examples of tourism-related environmental degradation include the destruction of delicate coral reefs by recreational scuba divers, ${ }^{6}$ reports of the Croatian city of Dubrovnik being "overwhelmed by mass tourism," and protests of Venetian residents against the tourist influx to the Italian city. ${ }^{8}$

An often-overlooked by-product of international travel is the impact of tourist-led food consumption on local agricultural food production. An example from Asia is the detrimental effect of tourism on the livelihood of indigenous farmers in Indonesia, who are being exploited by large scale food producers that exert a disproportionate influence on their agricultural practices. ${ }^{9}$ While the individual traveler may feel understandably powerless when faced with this issue, the lobbying potential of tourists with the travel industry is quite significant. Tourism Concern is a not-for-profit organization which seeks to protect the interests of local workers and the native environment. ${ }^{10}$ Responsible travelers should challenge their tour operator or adventure travel company if they do not subscribe to the Tourism Concern Charter.

A descriptive study of 101 Inca Trail porters in Peru demonstrated the neglect of local tourism employees, who have to routinely carry loads ranging from $20 \mathrm{~kg}$ to $45 \mathrm{~kg}$ on behalf of the trekkers. ${ }^{11}$ The study revealed concerns about porter clothing, shelter, equipment, and insufficient food provisions. Porters expressed a strong desire for improved working conditions. The study author, Dr. Irmgard Bauer, herself an active member of the ISTM Responsible Travel group, concluded that the responsibility for porter healthcare lies with travel health professionals and local health authorities. Travelers should also be mindful of the working conditions of porters, and they should ensure that these porters have appropriate footwear and access to medical care in the event of injury or illness.

Ecotourism is an example of tourism which involves the responsible interaction of tourists and the tourism industry. Ecotourism activities aim to educate visitors about the natural environment while minimizing damage to natural resources. The revenue generated by these activities is used to enhance the quality of life of local residents, and facilitate conservation of biodiversity and the local cultural heritage. Ecotourists should be made aware of infectious diseases which have been reported in travelers engaging in nature-based tourism. These include rabies, histoplasmosis, brucellosis and Japanese encephalitis. Nature-based tourists should also avoid activities that exploit wildlife for entertainment purposes, such as elephant riding or lion cub petting. They should also avoid purchasing products derived from animals which have been mistreated or unsustainably harvested.

\section{Medical Tourism}

Medical tourism refers to travel across international boundaries by individuals for the purpose of receiving medical care which is unavailable or too expensive in their home country. ${ }^{12}$ While medical tourism which is properly regulated and held to a high standard may have beneficial outcomes for individual patients, ${ }^{13}$ consideration should be afforded to the unintended consequences of this multi-billion-dollar global industry. There is a risk of displacement of the local medical workforce from the public healthcare system to the private sector in popular medical tourism destinations such as Thailand, India, and Malaysia. This imposes inevitable strains on the local delivery of public health services.

Traveling abroad for medical treatment also represents a challenge to the health service in the traveler's home country. An example of this is the importation of multi-drug resistant bacteria which have colonized medical tourists as a result of inadequate antibiotic stewardship during their treatment abroad. ${ }^{14}$ This is compounded by difficulties in transmitting operative reports and in communicating with the healthcare providers in the medical tourism destination. Organ transplant tourism typically involves the travel of a wealthy middle-aged patient from a developed country to a resourcepoor country for the purpose of receiving a solid organ transplant, such as a kidney or liver, from an impoverished donor. ${ }^{15}$ The medical follow-up of these unfortunate organ "vendors" is often woefully inadequate. A study by Naqvi et al in Bangladesh highlighted the fact that organ donors often suffered prolonged post-operative pain which hindered their ability to do manual work, rendering them and their families in a worse position financially. ${ }^{16}$

\section{Voluntourism}

Volunteering overseas can have a durable positive effect on a person's self-development. It brings with it the opportunity to develop new skills and enjoy cross-cultural experiences. These skills may be important to the young volunteer's future employment prospects. The ISTM Responsible Travel special interest group places strong emphasis on the importance of responsible international volunteering. Some international volunteering opportunities do not require pre-existing skills and may or may not involve pre-departure training. Such voluntourists are often poorly informed about their volunteering tasks and may find themselves exposed to uncomfortable and emotionally challenging situations in unfamiliar environments. The young voluntourist should be reminded of the necessity of behaving in a respectful manner towards the host community. This includes refraining from any exploitation of the local people, such as posting photographs 
without consent on social media. This particularly applies to volunteering episodes which involve contact with minors such as in local orphanages.

Health voluntourism carries additional risk for the local host community. Healthcare professionals should adopt a responsible approach when volunteering. They should reflect on the benefits of their contribution to the local people but also on the possibly negative long-term impact of their intervention. How does their volunteering effort fit in with the local health system, local health beliefs, and the expectations of the local community? Is there a danger that their efforts may be unsustainable, create an unnecessary dependency on external volunteers, and absolve the local authorities from their own responsibilities? For medical and nursing students in particular, it is unethical for voluntourists to work beyond the scope and level of their own training. Anecdotal reports suggest that medical elective students may be given opportunities to practice skills on local patients which would not be acceptable in the countries where they are being medically educated. A recent review article provides a detailed checklist of recommendations and web-based resources which may be used by universities in their predeparture training and briefing of medical elective students. ${ }^{17}$

\section{Sex Tourism}

There is a growing awareness of the phenomenon of sex tourism where travel is specifically arranged for, or by, travelers to facilitate sexual contacts abroad. Sex tourism also encompasses travelers who engage in casual sex with fellow travelers or local people, the latter of which may be forced to engage in prostitution for economic reasons. According to the ISTM Responsible Travel special interest group, over 250000 sex tourists travel to Asia each year. ${ }^{18}$ This may be an underestimation given the difficulty in obtaining reliable data on this sensitive subject. There may be a misconception that sex tourists are exclusively male. Bauer, in her review of female sex tourism, debunks this myth. She characterizes the typical female romance or sex tourist as being much wealthier than the male partners they seek. Older female sex tourists may be bored in their current home relationships, are often retired, and are therefore able to travel more frequently. ${ }^{19}$

Sex tourism may involve the exploitation of minors, especially in countries with a lower age of sexual consent than in the traveler's host country. The non-profit organization End Child Prostitution, Child Pornography and Trafficking of Children (ECPAT) estimates that over one million children worldwide are drawn into the sex trade every year. ${ }^{20}$ Many commercial sex workers have found themselves forced to engage with sex tourists as a result of being deceived by human trafficking networks. It is unlikely that the sex tourist will disclose his/her true motivation in the pre-travel consultation. They may not present for pre-travel health advice in order to avoid answering sensitive questions about their travel itinerary. This deprives them of preventive advice which would reduce their risk of contracting sexually transmitted infections such as chlamydia, gonorrhea, syphilis, and HIV. A cross-sectional study of 468 travelers revealed that $59.7 \%$ of them did not consistently use condoms, with one out of every four respondents never having used condoms during travel. ${ }^{21}$ Latin America and the Caribbean were identified as regions particularly associated with risky sexual behavior in tourists. The authors concluded that tourists should be educated in STI prevention and geographic HIV incidences before and during their travels. Furthermore, people living with HIV should be advised to communicate their status to their sexual contacts. The travel medicine practitioner, if suspicious that the purpose of travel is to engage in child sex tourism, has a duty to inform these individuals that there are legal consequences under the extraterritorial laws of their home country. The Republic of Ireland is among the countries that allow the prosecution of their citizens for committing child sex tourism acts abroad. ${ }^{22}$ Table 1 summarizes key recommendations promoting responsible travel.

\section{Conclusion}

This article has provided an overview of the detrimental effects of irresponsible tourism with a particular focus on environmental factors, medical tourism, the so-called voluntourism, and sex tourism. The leadership role of the ISTM in promoting responsible travel has been described.

Table 1. Checklist of Responsible Traveler Behaviors

\begin{tabular}{ll}
\hline Travel Issue & Recommendation \\
\hline Cultural awareness & Educate yourself about the destination and local culture. \\
Air travel & Register on a carbon offsetting program. \\
Local transport & Choose public transport or hire electric or hybrid vehicles. \\
Tour operators & Support responsible tour providers which do not exploit local workers and subscribe to the Tourism Concern Charter. \\
Accommodation & Enquire about your hotel or guest house's sustainability practices. \\
Waste generation & Reduce, reuse, recycle, refuse. \\
Environment & Unplug your electrical device chargers and turn off lights. \\
Water conservation & Take shorter showers instead of baths in hotels. \\
Respect locals & Ask for permission before taking photographs. \\
Endangered species & Do not purchase products derived from endangered species. \\
Local economy & Purchase locally produced souvenirs and eat at local restaurants. \\
Local laws & Do not support the illegal drug trade or commercial sex trade. \\
Religious traditions & Avoid behaviors which would offend local religious sensibilities. \\
\hline
\end{tabular}


Further research is needed to better understand the attitudes of travelers, travel health professionals, and the travel industry towards responsible tourism and to overcome barriers to its implementation. With a concerted effort to collaborate in the best interests of the destination communities who host us, we can all ensure that we only leave light footprints when we travel.

\section{Authors' Contributions}

Both authors contributed equally to the conception, planning, writing, and editing of the article. The final version was read and approved by both authors.

\section{Conflict of Interest Disclosures}

None declared.

\section{Ethical Approval}

Not applicable.

\section{Funding/Support}

None received.

\section{References}

1. World Tourism Organization. Tourism Towards 2030/Global Overview. Madrid: World Tourism Organization; 2011.

2. Glaesser D, Kester J, Paulose H, Alizadeh A, Valentin B. Global travel patterns: an overview. J Travel Med. 2017;24(4). doi:10.1093/ jtm/tax007.

3. International Society of Travel Medicine. Responsible Travel Group. 2018. http://www.istm.org/responsibletravelgroup. Accessed 23 January 2018.

4. Flaherty GT, Lim Yap K. Bibliometric analysis and curriculum mapping of travel medicine research. J Travel Med. 2017;24(5). doi:10.1093/jtm/tax024.

5. Carbon Footprint. Carbon offsetting. 2018. https://www. carbonfootprint.com/carbonoffset.html. Accessed 23 January 2018.

6. Roche RC, Harvey CV, Harvey JJ, et al. Recreational Diving Impacts on Coral Reefs and the Adoption of Environmentally Responsible Practices within the SCUBA Diving Industry. Environ Manage. 2016;58(1):107-116. doi:10.1007/s00267-016-0696-0.

7. Croatian city of Dubrovnik overwhelmed by mass tourism. France 24 website. 12 July 2017. http://www.france24.com/en/20170712- focus-croatia-mass-tourism-dubrovnik-old-city-tourists-cruisesunesco-world-heritage-site. Accessed 23 January 2018.

8. The Local it. Venice residents protest against tourist influx. 2017. https://www.thelocal.it/20170703/venice-residents-protestagainst-tourist-influx-mass-tourism-mi-no-vado-via. Accessed 23 January 2018.

9. Channel News Asia. 2017 Social network founder turns champion for exploited farmers in Indonesia. https://www.channelnewsasia. com/news/cnainsider/regopantes-app-champion-exploitedfarmers-indonesia-fair-price-9815254. Accessed 23 January 2018.

10. Tourism Concern. Ethical travel guide. 2018. https://ethical.travel/. Accessed 23 January 2018.

11. Bauer IL. Inca Trail porters: the health of local tourism employees as a challenge for travel medicine. J Travel Med. 2003;10(2):94-99. doi:10.2310/7060.2003.31654

12. Chen LH, Wilson ME. Medical tourism. J Travel Med. 2015;22(3):218. doi:10.1111/jtm.12190.

13. Gholami M, Jabbari A, Kavodi Z, Gholami M. Service quality in Iran's medical tourism: hospitals in Shiraz city. Int J Travel Med Glob Health. 2016;4(1):19-24. doi:10.20286/ijtmgh-040119.

14. Reinheimer C, Kempf VAJ, Jozsa K, et al. Prevalence of multidrugresistant organisms in refugee patients, medical tourists and domestic patients admitted to a German university hospital. BMC Infect Dis. 2017;17(1):17. doi:10.1186/s12879-016-2105-y.

15. Akoh JA. Key issues in transplant tourism. World J Transplant. 2012;2(1):9-18. doi:10.5500/wjt.v2.i1.9.

16. Naqvi SA, Ali B, Mazhar F, Zafar MN, Rizvi SA. A socioeconomic survey of kidney vendors in Pakistan. Transpl Int. 2007;20(11):934939. doi:10.1111/j.1432-2277.2007.00529.x.

17. Johnston N, Sandys N, Geoghegan R, O'Donovan D, Flaherty G. Protecting the health of medical students on international electives in low-resource settings. J Travel Med. 2018;25(1). doi:10.1093/ jtm/tax092.

18. Oppermann M. Sex tourism. Ann Touris Res. 1999;26(2):251-266. doi:10.1016/S0160-7383(98)00081-4.

19. Bauer IL. Romance tourism or female sex tourism? Travel Med Infect Dis. 2014;12(1):20-28. doi:10.1016/j.tmaid.2013.09.003.

20. ECPAT International 2018. http://www.ecpat.org/. Accessed 23 January 2018

21. Alcedo S, Kossuth-Cabrejos S, Piscoya A, Mayta-Tristan P. Factors associated with non-use of condoms in an online community of frequent travellers. Travel Med Infect Dis. 2014;12(6 Pt B):750756. doi:10.1016/j.tmaid.2014.10.003.

22. Government of Ireland. Irish Statute Book. Sexual Offences (Jurisdiction) Act, 1996. http://www.irishstatutebook.ie/eli/1996/ act/38/enacted/en/html. Accessed 23 January 2018. 